\title{
EDitorial
}

\section{Crisis, curriculum and citizenship}

\section{Carol Mutch}

- 4 September 2010, an earthquake measuring 7.1 on the Richter scale rocks Canterbury causing widespread damage to buildings and infrastructure.

- 19 November 2010, 29 miners and contractors are killed in an explosion at the Pike River mine on the West Coast.

- 22 February 2011, 182 die and thousands more are injured or made homeless in a 6.3 earthquake centred closer to the city of Christchurch.

- 13 June 2011, another 6.3 quake in Christchurch, amid the 7,000+ aftershocks, further damages an already vulnerable city and surroundings.

In a year of unprecedented events in New Zealand's history, in which I was to lose people close to me and in which I saw firsthand the toll taken on my hometown community of Greymouth and my current place of residence, Christchurch, I cannot reflect on this year in curriculum without relating it to those events. As I write this, the clean-up of the oil spill following the Rena's grounding off Tauranga is also underwayanother example to support the points I will make.

In this editorial I would like to tie together notions of crisis, curriculum and citizenship. In a previous Curriculum Matters editorial, I presented a broad definition of curriculum (Mutch, 2009). This explored curriculum from society's aspirations, through official documents, to teachers' interpretations and students' responses. In the 2011 editorial, I will link the way in which the official curriculum has interpreted society's aspirations and how the responses to the disasters of the past year demonstrate particular ways in which New Zealanders act as citizens when faced with major crises. 


\section{Editorial}

First, what are society's aspirations, as presented in the formal curriculum for schools? The New Zealand Curriculum (Ministry of Education, 2007, p. 8) states that the vision is for young people:

- who will be creative, energetic, and enterprising

- who will seize the opportunities offered by new knowledge and technologies to secure a sustainable social, cultural, economic, and environmental future for our country

- who will work to create an Aotearoa New Zealand in which Māori and Pākehā recognise each other as full Treaty partners, and in which all cultures are valued for the contributions they bring

- who, in their school years, will continue to develop the values, knowledge, and competencies that will enable them to live full and satisfying lives

- who will be confident, connected, actively involved, and lifelong learners.

If we compare these aspirations to definitions of citizenship, we find many similarities. Rather than a narrow term related only to patriotism or nationhood, the literature provides definitions of citizenship that are more fluid and contested. As Rob Gilbert explains (1996, p. 108): "Some definitions emphasise the nation state as an entity to which people should give allegiance and loyalty. Other definitions emphasise individual rights or a sense of shared loyalty. Others focus on citizen participation in government." John Cogan and Ray Derricott (1998) view citizenship as a set of multidimensional characteristics which are necessary for young people to take their place in the world of the future. These are around co-operation, participation and environmental responsibility but also the capacity to think in critical and systemic ways. Other characteristics include understanding, accepting and tolerating cultural differences, resolving conflict in a nonviolent manner and defending human rights.

What is the role of curriculum in this preparation of young people for citizenship of the future? David Kerr (2000) views the role of education for citizenship, through curriculum and pedagogy, as broad and encompassing. Citizenship education is not, therefore, limited to particular subject areas or places in the timetable but is part of formal and informal, in-school and out-of-school learning. 
In their study of school programmes, Westheimer and Kahne (2004) found three conceptions of the "good citizen" underpinned approaches to education for citizenship-personally responsible, participatory and justice-oriented. They claim that each of these conceptions has an underlying ideological perspective, which presupposes particular views of society and the role of schools in preparing citizens for that society. These views become embedded in school curricula and, in turn, influence the ways that students come to understand society and their role in it.

Programmes that aim to produce personally responsible citizens focus on individual character traits such as honesty, integrity, self-discipline, respect, courtesy and compassion. The assumption is that society will become a better place if everyone acts responsibly and with self-discipline. While such traits and dispositions are essential for the sound functioning of society, critics of this view feel that they do not encourage collective action or ask students to look more deeply at the causes of injustice and inequality.

Programmes that aim to produce participatory citizens set out to encourage students to actively participate in school, community, local and national affairs. Skills of communication, collaboration and facilitation are fostered to bring collective and creative solutions to societal problems. Westheimer and Kahne question, however, whether programmes designed to encourage civic participation necessarily promote students' capacities for critical analysis and social change.

Finally (although Westheimer and Kahne state clearly that their three conceptions are not an exhaustive list), there are programmes that promote justice-oriented citizens. In order to do this, it is important to go beyond an understanding of rules and laws or the functioning of government, to examine the social, political and economic forces that shape society and how these allow inequity and injustice. Westheimer and Kahne again caution that a focus on learning about social justice might not necessarily lead to effective social action.

What can we learn from the responses of everyday New Zealanders to the Canterbury earthquakes and the Pike River mine disaster? What kinds of citizen were portrayed in the responses to these crises? Were these the kinds of citizen the curriculum is aiming to foster? 


\section{Editorial}

Both disaster situations provided numerous examples of the personally responsible citizen, including those who donated money and goods for disaster relief. The outpouring of grief and support was highly visible as ordinary New Zealanders found ways to communicate their empathy through words, gifts, money and services. As I spent time with my family on the West Coast, the community was overwhelmed with letters, cards, flowers and tributes that arrived each day and were displayed in the community centre. Mail for individual families arrived by the bag and groceries by the carton. The phone rang constantly with condolences, good wishes and offers of support. Similarly, throughout the earthquakes and aftershocks, Cantabrians knew that they were not alone.

Throughout the disaster recovery processes there were also many examples of the participatory citizen. The earthquakes led to the mobilisation of students, farmers, communities and many others who set up volunteer groups to cover a wide range of needs. The Student Volunteer Army provides an interesting case study of youth participation. Sam Johnson, the University of Canterbury student who used Facebook to set up the volunteer system for the first earthquake, epitomised the many qualities that citizenship education - or, indeed, The New Zealand Curriculumsets out to foster. He and the many thousands of young people who came from all over Christchurch-and, for the February earthquake, from all over the country - to shovel liquefaction were certainly "confident, connected and actively involved" citizens.

Finally, there were examples, although not as numerous, of the justiceoriented citizen who sought to focus on underlying causes of injustice, whether for the Pike River miners and their families or for those disadvantaged by decision-making processes relating to earthquake recovery. Bernie Monk, who lost his son, Michael, in the Pike River disaster, became the spokesperson for many of the families who lost loved ones in the mine. This was, and still is, a huge commitment of time, energy and resource which he has given willingly to ensure that the families have strong collective voice in dealing with the event, the aftermath, the media, the politics and the ongoing investigations.

If the curriculum does aim to prepare young people for their role as citizens, and has done so over time, what then is the result? Without prompting, 
many New Zealanders took on the roles of personally responsible and participatory citizens, finding thoughtful, practical and creative ways to provide support and help. Some, even at great personal cost, took on bigger causes and sought to address the underlying systemic issues that were creating unfairness or injustice. In times of disaster, it seems that we as New Zealanders display many of Cogan's multidimensional characteristics, but is there still room to go further and see our roles as citizens in the broader context of the ongoing pursuit of equity and social justice? As Westheimer and Kahne (2004) remind us, while the curriculum, and the goal of education for citizenship, might be successful in meeting the outcomes that have been set, how these outcomes are framed carries "political choices with political consequences" (p. 237).

And so to this year's issue of Curriculum Matters. In what ways do these articles have us view curriculum more critically and systemicallyas political choices with political consequences? The first article by Margaret Walshaw and Roger Openshaw picks up this theme with their statement that, "Curriculum is an expression of political purpose." Through an analysis of parliamentary debates, Walshaw and Openshaw place discussions of mathematics education into various political and ideological contexts thereby highlighting competing discourses.

Contradictory and contested notions of curriculum, or areas within the curriculum, are recurring themes in this issue. Tanya Samu examines discursive formations of diversity and argues that under-theorising of the notion of diversity has led to lack of clarity in curriculum policy. Jane Abbiss discusses the ideological tensions and mixed messages in social sciences education, while Philippa Hunter explores contested conceptualisations of history. Cardow and Kirkley discuss the mismatch between curriculum intentions and curriculum interpretation in relation to the place of entrepreneurship in secondary schools.

Responses to culture and diversity are another set of themes-mention has already been made of Samu's discussion of diversity. Rawiri Hindle and colleagues discuss equity and diversity at the level of teacher practice. They report on results of their study into culturally responsive pedagogy through the arts curriculum. Sharyn Heaton offers a challenge to curriculum developers who borrow epistemological concepts from one 


\section{Editorial}

cultural context for use in another-in her case, hauora — and in so doing enhance confusion and contradiction with their cultural appropriation. An alternative view of culturally specific educational practice comes in Glenda Anthony and Liping Ding's comparison of Chinese and New Zealand mathematics textbooks.

Anthony and Ding's article also highlights the range of data sources and methods used by curriculum researchers. They used the textbook as a "site of inquiry", Walshaw and Openshaw used parliamentary debates while Hunter supplemented document analysis with her personal experience. Hindle et al. observed classrooms while Cardow and Kirkley interviewed teacher education students. As a cross-disciplinary study, a broad range of philosophical, theoretical and methodological options is available to curriculum scholars. In Taylor and Bailey's article, for example, the authors subscribe to radical constructivism, Samu uses Foucault, Rowena Taylor underpins her discussion with Layton's theory of subject maturation and Hunter uses critical pedagogy_all adding to the richness of curriculum scholarship.

While Curriculum Matters aims to explore a wide range of topics under the curriculum umbrella, two particular areas of the school curriculum have added emphasis in this issue due to the number of articles on each. There are three articles each on social sciences and mathematics education. Taylor reports that NCEA and curriculum alignment have contributed to strengthening social sciences education in terms of relevance, pedagogy and coherence. Abbiss finds, however, that the social sciences curriculum contains too many mixed messages while Hunter offers an alternative and more radical interpretation of the place of history in the curriculum. The mathematics articles also take differing but complementary perspectivescurriculum as contested history (Walshaw and Openshaw), textbooks as de facto curriculum (Anthony and Ding) and curriculum as a constructive and creative activity (Taylor and Bailey). There is also an interesting spread across other curriculum areas and themes, including curriculum as preparation for future citizenship, through the content of particular articles, such as Rose Hipkins' exploration of the development of key competencies or Cardow and Kirkley's discussion of an entrepreneurial orientation. 
Finally, Walshaw and Openshaw (in this issue) remind us that, "Curriculum is created within shared space, time, history and possibility." Reflecting on this year in curriculum, how have we been impacted upon by space, time, history and possibility? How will history view the events of this year and the relationship between crisis, curriculum and citizenship? What will we learn from this, what will the curriculum of the future hold and how will it reflect who we are and who we aspire to be?

\section{References}

Cogan, J., \& Derricott, R. (1998). Citizenship for the 21st century: An international perspective on education. London: Kogan Page.

Gilbert, R. (1996). Studying society and environment: A handbook for teachers. Melbourne: Macmillan Education.

Kerr, D. (2000, April). Citizenship education: An international comparison across 16 countries. Unpublished paper presented at the American Educational Research Association conference, New Orleans.

Ministry of Education. (2007). The New Zealand curriculum. Wellington: Learning Media.

Mutch, C. (2009). Editorial: Curriculum: What, how and for whom? Curriculum Matters, 5, 1-5.

Westheimer, J., \& Kahne, J. (2004). What kind of citizen? The politics of educating for democracy. American Educational Research Journal, 41(2), 237-269.

\section{The author}

Carol Mutch is an associate professor in the School of Critical Studies in Education at The University of Auckland. Formerly a teacher, teacher educator and policy adviser, Carol's research and writing interests are in educational research and evaluation, curriculum and education policy, social sciences and citizenship education. 